\title{
Retraction: X. Ma et al. Hybrid Endovascular Repair in Aortic Arch Pathologies: A Retrospective Study. Int. J. Mol. Sci. 2010, 11, 4687-4696
}

\author{
Mark L. Richter ${ }^{1}$ and International Journal of Molecular Sciences Editorial Office ${ }^{2}$
}

Received: 17 December 2015; Accepted: 17 December 2015; Published: 18 December 2015

1 Department of Molecular Biosciences, the University of Kansas, Lawrence, KS 66045, USA; richter@ku.edu

2 MDPI AG, Klybeckstrasse 64, 4057 Basel, Switzerland; ijms@mdpi.com

We have been made aware that the figures and experimental data reported in the title paper [1] are duplicated in another publication by P. Bergeron [2]. MDPI is a member of the Committee on Publication Ethics and takes the responsibility to enforce strict ethical policies and standards very seriously. To ensure the addition of only high quality scientific works to the field of scholarly publication, paper [1] is retracted and shall be marked accordingly. We apologize to our readership that this went undetected until now.

\section{Reference}

1. Ma, X.; Guo, W.; Liu, X.; Yin, T.; Jia, X.; Xiong, J.; Zhang, H.; Wang, L. Hybrid Endovascular Repair in Aortic Arch Pathologies: A Retrospective Study. Int. J. Mol. Sci. 2010, 11, 4687-4696. [CrossRef] [PubMed]

2. Bergeron, P.; Mangialardi, N.; Costa, P.; Coulon, P.; Douillez, V.; Serreo, E.; Tuccimei, I.; Cavazzini, C.; Mariotti, F.; Sun, Y.; Gay, J. Great Vessel Management for Endovascular Exclusion of Aortic Arch Aneurysms and Dissections. Eur. J. Vasc. Endovasc. Surg. 2006, 32, 38-45. [CrossRef] [PubMed]

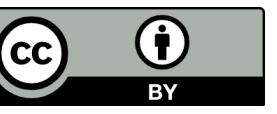

(C) 2015 by the authors; licensee MDPI, Basel, Switzerland. This article is an open access article distributed under the terms and conditions of the Creative Commons by Attribution (CC-BY) license (http:/ / creativecommons.org/licenses/by/4.0/). 